\title{
Glutathione S- Transferase M1 in the Serum of Patients with Endometriosis
}

\author{
Zahra Sorkhoo ${ }^{1}$ \\ ${ }^{1}$ Gilan University, Iran \\ Correspondence: Zahra Sorkhoo, Gilan University, Iran. E-mail: zsorkhou@gmail.com
}

Received: July 4, 2016

Accepted: September 26, 2016

Online Published: October 17, 2016

doi:10.5539/jmbr.v6n1p67

URL: http://dx.doi.org/10.5539/jmbr.v6n1p67

\begin{abstract}
Endometriosis is a female disease with high incidence and unknown causes because of the presence of endometrial tissue outside of the uterine wall. Glutathione S- transferase (GSTs) is a key enzyme in phase I and II that catalyzes the conjugation of glutathione to genotoxic compounds. Glutathione S- transferase M1 (GSTM1) is a versatile enzyme that plays an important role in detoxification of carcinogenic metabolites. The aim of this study was to evaluate serum levels GSTM1 in patients with endometriosis. In this study, blood samples from 20 women with endometriosis and 20 healthy women were collected. The final concentration of protein in the blood of patients (TPC) and GSTM1 in serum by using "biuret" and enzyme-linked immunosorbent assay "(ELISA) were measured. It was shown that the level of total protein concentration all samples are within the normal range and no significant changes between the two groups were seen. Although significant reduction in serum levels GSTM1 was observed in patients with Endometriosis compared to the control group $(\mathrm{P}=0.002)$. The results of this study showed that GSTM1 is involved pathophysiology of endometriosis.
\end{abstract}

Keywords: endometriosis, Glutathione S- Transferase, infertility

\section{Introduction}

Endometriosis is the presence of endometrial tissue outside the uterus is believed to play an important role in infertility (Thornton, Morley, Lilleyman \& Onwude, 1997). In general, women with endometriosis suffer from 15$7 \%$ of the total population $((\mathrm{Wu}, \mathrm{Lu}$, Chuang \& Tsai, 2010. In addition to free radical agents, immunological factors and environmental factors, genetic factors are the main factors in the development of endometriosis due to the following factors are made.

\subsection{Glutathione-S-transferase gene M1 (GSTM1)}

Glutathione-S-transferase M1 gene is set on chromosome 1p13 and expresses the enzymes GSTM1 (Zhong, Wolf \& Spurr, 1992). Glutathione is involved in detoxification xenobiotic and carcinogens (Mannervik et al., 1992). GSTM1 gene deletion on the impact and cause defects in the detoxification enzyme and the risk of exposure to carcinogens and toxic chemicals will increase (Seidegard, Vorachek, Pero \& Person, 1988). GSTM1 gene deletion in diseases such as ovarian cancer (Baxter, Thomas \& Campbell, 2001), Cystic fibrosis (Baranova et al., 1997), gastric cancer Harada et al., 1992), lung cancer (Nakachi et al., 1993) and bladder cancer (Brockmoller et al., 1994) have been reported. Studies have shown that GSTM1 gene is removed in a high percentage of women with endometriosis (Nisolle et al., 1990).

\subsection{Tumor Suppressor Gene p53}

This gene creates p53 protein that this protein affects suppressor genes, such as Bax, P21 and plays a role in cell cycle regulation, cell growth and apoptosis. P53 gene suppresses tumor action that mutations in this gene will lead to tumor formation (Hsieh \& Lin, 2006).

\subsection{Metalloproteinase Matrix Gene-9 (MMP-9)}

Enzyme products of these genes are involved in extracellular matrix degradation. The histologic endometrial changes during the menstrual cycle enzymes are involved. These enzymes play an important role in the analysis of extracellular matrix and enables endometrial cells that are integrated into the peritoneum of aggressive endometrial lesions. A study was accomplished on polymorphisms -1562C > T, R279Q, P574R gene (9- MMP) in 
women. Han suggested that haplotype AC, GG, CA gene (9-MMP) are associated with the progression of the disease. (Han et al., 2009).

Lin. (Hur, Lee, Moon \& Chung, 2005) and colleagues in 2003 showed that GSTM1 genotype is associated with risk of developing endometriosis (Lin et al., 2003).

In 2012, Vichi et al. showed GSTM1 gene polymorphisms with risk of developing endometriosis (Vichi et al., 2012). Ertunc and colleagues in 2005 examined that a member of the family GSTP1 GST is associated with risk of developing endometriosis risk. The results show GSTP1 polymorphism associated with the risk of endometriosis risk (Ertunc et al., 2005). In 2004 Ding and his colleagues examined the correlation between GSTM1 and risk of developing endometriosis in population of Sinn Yang, China and they did not observe the correlation (Ding et al., 2004). Tempfer, Schneeberger and Huber reported in 2004 that GSTM1 polymorphisms as genetic factors susceptibility to diseases are benign and malignant gynecologic diseases (Tempfer et al., 2004).

In general, GST family plays an important role in detoxification. Therefore, according to the role of environmental factors in this disease and GST in detoxification; in this study, the GSTM1 was discussed on patients with endometriosis.

\section{Materials and Methods}

In order to cater to the amount of $5 \mathrm{ml}$ of blood serum, blood was taken from 20 patients and 20 controls. Healthy female control subjects with no symptoms associated with endometriosis and infertility, cysts and endometriosis had no family history. Blood samples for 20 minutes at room temperature or $37^{\circ} \mathrm{C}$ was placed in a water bath. Then, it was centrifuged for $15 \mathrm{~min}$ at 6000 . Solution $-70^{\circ} \mathrm{C}$ was kept until to be used.

Test tubes after cleaning the samples were numbered. Then, $50 \mathrm{ml}$ of standard solution was shed in a tube and 50 $\mathrm{ml}$ of biuret reagent was added to the tubes. The tubes were shaken well and then in the water bath for 10 min. ${ }^{\circ} \mathrm{C} 37$ temperature. Then, using absorption spectrophotometer and standard samples was read at $540 \mathrm{~nm}$ and was calculated using the following formula:

$$
\frac{\text { OD.T }}{\text { OD.ST }} \times 6 \text { Concentration of protein }
$$

In the present study, to evaluate the GSTM1 in the sera of ELISA kits CASABIO, GSTM1 CSB-EL009979HV catalog numbers were used.

To prepare the samples, we act as follows:

- biotin - antibody $(\times 1)$ : Before opening it was centrifuged. Biotin - antibody dilution would require 100 times the dilution contains 10 biotin - antibody diluent $\mathrm{L} \mu 990$ plus biotin antibodies.

- avidin HRP- $(\times 1)$ : jar before opening was centrifuged. Avidin Hrp - requires dilution before us, which is 100 dilution for $\mathrm{L} \mu 10 \mathrm{HRP}$ - avidin avidin HRP- diluent is added to $\mathrm{L} \mu 990$.

- Washing buffer $(\times 1)$ : if crystals formed in concentration to warm to room temperature and mix gently until the crystals are completely gone away. $20 \mathrm{ml}$ wash buffer concentration $(\times 25)$ was diluted with deionized distilled water to wash buffer ml500 $(\times 1)$.

- Standard solution GSTM1: GSTM1 diluent was used to prepare a series of diluted solution.

To prepare sample $100 \mathrm{~L} \mu$ standard was added to each well. Then, the coated plates were covered with adhesive tape and were incubated for $2 \mathrm{~h}$ at $37^{\circ} \mathrm{C}$. Liquid of each well was replaced, but it was not washed. $1 \mu 100$ biotin antibody $(\times 1)$ was added to each well. Again, it was covered with adhesive tape and was incubated for $1 \mathrm{~h}$ at $37^{\circ}$ C. Each well was washed. This washing process was repeated 2 times for a total of 3 washes. By filling each well was washed with washing buffer $2001 \mu$ remain and 2 minutes at room temperature. $1 \mu 100$ avidin HRP- $(\times 1)$ was added to each well and this was covered with sticky strips were incubated for $1 \mathrm{~h}$ at $37^{\circ} \mathrm{C}$. Washing process was repeated 5 times. $\mathrm{L} \mu 90 \mathrm{TMB}$ substrate was added to each well and were incubated at $37^{\circ} \mathrm{C}$ for $30-15$ minutes. L $\mu 50$ stop solution was added to each well. At this stage, the wells were placed in the ELISA reader and optical density was read at $450 \mathrm{~nm}$. According to the optical density of a plot device and according to the optical density, the samples was investigated GSTM1 concentration.

\section{Findings}

Using biuret method, total protein content sera from healthy individuals and patients with endometriosis were measured and it was found containing concentrations of total serum protein in serum of patients with endometriosis than in healthy subjects showed no significant difference $(4 / 0 \mathrm{P}=)$ (Figure 1). The ELISA technique to study protein level GSTM1 in patients with endometriosis compared with healthy subjects showed that the average

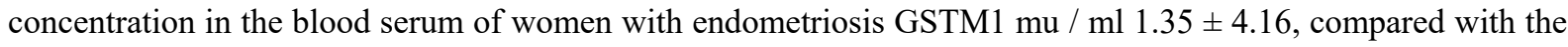


average concentration of serum GSTM1 healthy female blood $\mathrm{mu} / \mathrm{ml} 1.79 \pm 5.82$ decreased significantly show that at $\mathrm{P}=0.002$ (Figure 2).

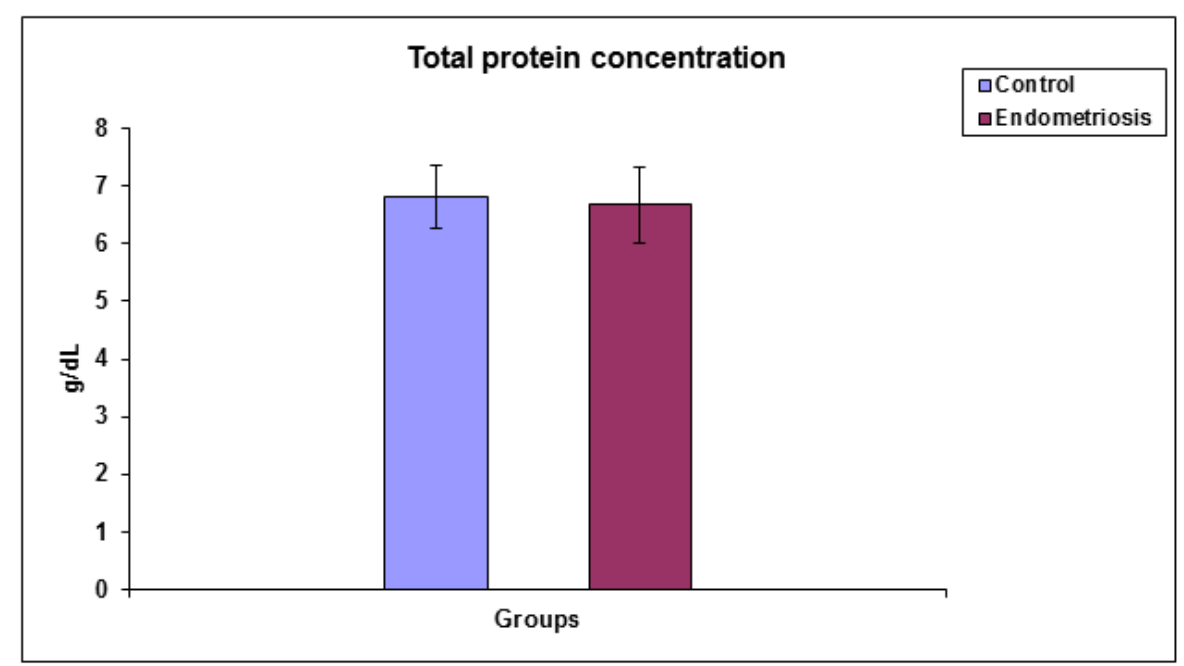

Figure 1. The concentration of serum total protein in the control group and patients with endometriosis that difference is not statistically significant. $(\mathrm{P}=0.4)$

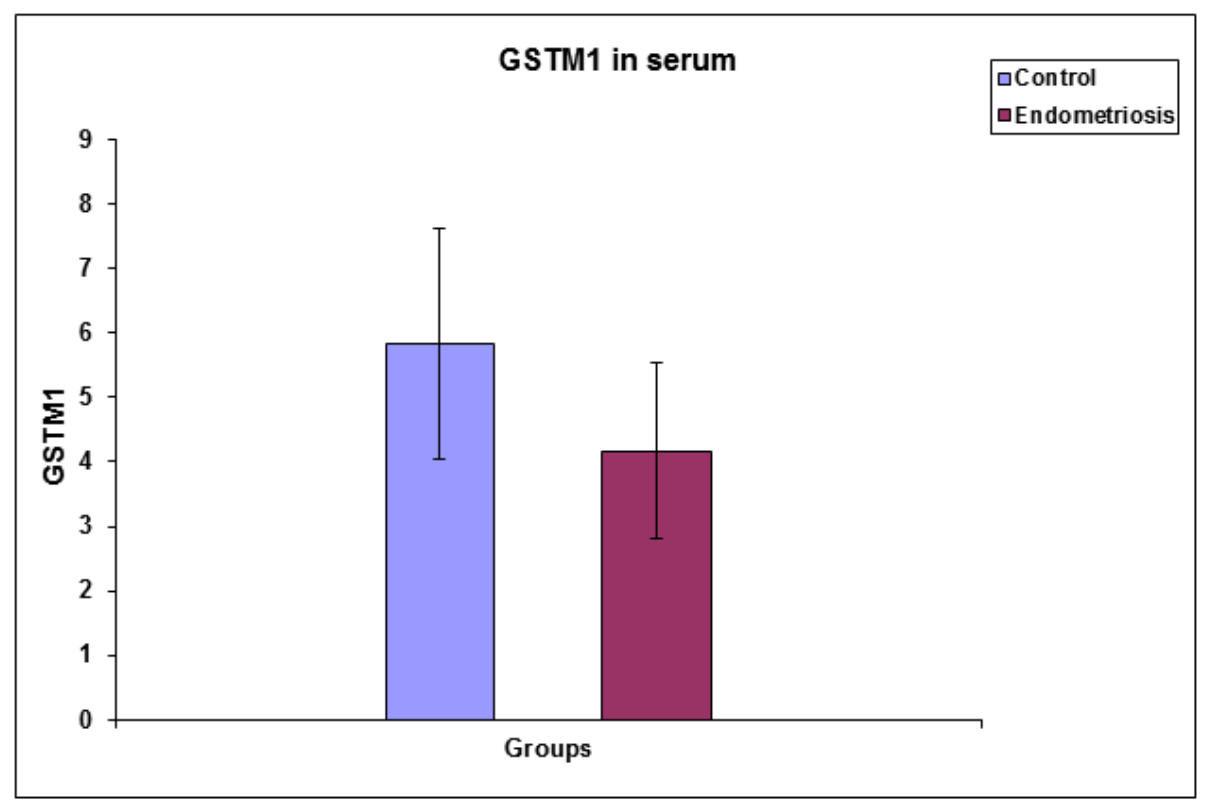

Figure 2. GSTM1 concentration in the blood serum of women with endometriosis and a control group, the difference was statistically significant $(\mathrm{P}=0.002)$.

\section{Discussion and Conclusion}

The results showed that GSTM1 significantly reduced in the serum of patients with endometriosis than in the control groups, but the concentration of protein in the two groups showed no significant change.

Studies show that removing the GST genes seen in patients with endometriosis. Thus GSTM1 is reduced in the serum of these patients due to removal in GST gene. It was concluded that GSTM1 plays a role in the physiology of endometriosis. 


\section{References}

Baranova, H., Bothorishvilli, R., Canis, M., Albuisson, E., Perriot, S., Glowaczower, E., ... Malet, P. (1997). GlutathioneS-transferase M1 gene polymorphism and susceptibility to endometriosisin a French population. Molecular Human Reproduction, 3, 775-780.

Baxter, S. W., Thomas, E. J., \& Campbell, I. G. (2001). GSTM1 null polymorphismand susceptibility to endometriosis and ovarian cancer. Carcinogenesis, 22, 63-5.

Brockmöller, J. I., Cascorbi, I., Kerb, R., \& Roots. I. (1996). Combined analysis of inherited polymorphisms in arylamine $\mathrm{N}$-acetyltransferase 2, glutathione S-transferases M1 and T1, microsomal epoxide hydrolase, and cytochrome P450 enzymes as modulators of bladder cancer risk. Cancer Research, 56, 3915-25.

Ding, Y., Chen, Z. F., Lin, R. Y., Wang, X. F., Ding, J. B., Ai, X. Z., \& Wen, H. (2004). Relationship between endometriosis and glutathione S-transferase M1, T1 genes of the Uygurs and Hans in Xinjiang. Zhonghua fu chan ke za zhi, 39, 101-4.

Ertunc, D., Aban, M., Tok, E. C., Tamer, L., Arslan, M., \& Dilek, S. (2005). Glutathione-S-transferase P1 gene polymorphism and susceptibility to endometriosis. Human reproduction, 20, 2157-61.

Han, Y. J., Kim, H. N., Yoon, J. K., Yi, S. Y., Moon, H. S., Ahn, J. J., Kim, H. L., \& Chung, H. W. (2009). Haplotype analysis of the matrix metalloproteinase- 9 gene associated with advanced-stageendometriosis. Fertility and sterility, 91, 2324-30.

Hsieh, Y., \& lin, C. (2006). P53 codon 11, 72, and 248 gene polymorphisms in endometriosis. International Journal of Biological Science, (4), 188-193.

Hur, S. E., Lee, J. Y., Moon, H. S., \& Chung, H. W. (2005). Polymorphisms of the genes encoding the GSTM1, GSTT1 and GSTP1 in Korean women: no association with endometriosis. Molecular Human Reproduction, $11,15-9$.

Lin, J., Zhang, X., Qian, Y., Ye, Y., Shi, Y., Xu, K., \& Xu, J. (2003). Glutathione S-transferase M1 and T1 genotypes and endometriosis risk: a case-controlled study. Chinese Medical Journal, 116, 777-80.

Mannervik, B., Awasthi, Y. C., Board, P. G., Hayes, J. D., Dillio, C., Ketterer, B., ... Pearson, W. R. (1992). Nomenclature for human glutathione transferases. Biochemical Journal, 282, 305-306.

Nisolle, M., Paindaveine, B., Bourdon, A., Berliére, M., Casanas-Roux F., \& Donnez, J. (1990). Histologic study of peritoneal endometriosis in infertile women. Fertility and sterility, 53, 984-8.

Seidegard, J., Vorachek, W. R., Pero, R. W., \& Person W. R., (1988). Hereditary differences in the expression of the human glutathione transferaseavtive on trans-stilbene oxide are due to a gene deletion. Proceedings of the National Academy of Sciences of the United States of America, 85, 7293-7297.

Tempfer, C. B., Schneeberger, C., \& Huber, J. C. (2004). Applications of polymorphisms and pharmacogenomics in obstetrics and gynecology. Pharmacogenomics, 5, 57-65.

Thornton, J. G., Morley, S., Lilleyman, J., \& Onwude, J. L. (1997). Currie I and Crompton AC human endometrium: glandular epithelial cell apoptosis is associated with increased expression of bax. The Journal of clinical endocrinology and metabolism, 82, 2738-2746.

Vichi, S., Medda, E., Ingelido, A. M., Ferro, A., Resta, S., Porpora, M. G., Abballe, A., Nisticò, L., De Felip, E., Gemma, S., \& Testai, E. (2012). Glutathione transferase polymorphisms and risk of endometriosis associated with polychlorinated biphenyls exposure in Italian women: a gene-environment interaction Fertility and sterility, 97, 1143-51.e1-3.

Wu, M.Y., Lu, C. W., Chuang, P. C., \& Tsai S. J. (2010). Prostoglandin E2: the master of endometriosis? Experimental biology and medicine (Maywood, N.J.), 235, 668-677.

Zhong, S., Wolf, C. R., \& Spurr, N. K. (1992). Chromosomal assignment linkage analysis of the human glutathione S-transferase mu gene (GSTM1) using specific polymerase chain reaction. Human genetics, 90, 435-9.

\section{Copyrights}

Copyright for this article is retained by the author(s), with first publication rights granted to the journal.

This is an open-access article distributed under the terms and conditions of the Creative Commons Attribution license (http://creativecommons.org/licenses/by/4.0/). 